\title{
Numerical Taxonomy of Old World Phlebotominae (Diptera: Psychodidae). \\ 2. Restatement of Classification upon Subgeneric Morphological Characters
}

\author{
Philippe Rispail/ ${ }^{+}$, Nicole Léger* \\ Laboratoire d'Ecologie Médicale et Pathologie Parasitaire (Pr J-P Dedet), Faculté de Médecine, \\ 163 rue Auguste-Broussonet, 34090 Montpellier, France *Laboratoire de Parasitologie, Faculté de Pharmacie, \\ 51 rue Cognacq-Jay, 51090 Reims CEDEX, France
}

\begin{abstract}
Numerical analyses (correspondence analysis, ascending hierarchical classification, and cladistics) were done with morphological characters of adult phlebotomine sand flies. The resulting classification largely confirms that of classical taxonomy for supra-specific groups from the Old World, though the positions of some groups are adjusted. The taxa Spelaeophlebotomus Theodor 1948, Idiophlebotomus Quate \& Fairchild 1961, Australophlebotomus Theodor 1948 and Chinius Leng 1987 are notably distinct from other Old World groups, particularly from the genus Phlebotomus Rondani \& Berté 1840. Spelaeomyia Theodor 1948 and, in particular, Parvidens Theodor \& Mesghali 1964 are clearly separate from Sergentomyia França \& Parrot 1920.
\end{abstract}

Key words: Old World sand flies - Psychodidae Phlebotominae - numerical taxonomy

Since the description of Bibio papatasi (Scopoli 1786) and the erection of the genus Flebotomus (Rondani 1840, Loew 1845), the taxonomy of phlebotomine sand flies has been based on monothetic principles, supported by morphological arguments. Successive classifications depended on a small number of subjectively chosen characters of adults, each credited a priori with discriminatory value and used to determine dichotomies. Thus erect or recumbent abdominal setae were used to identify two groups, Phlebotomus and Sergentomyia, first as subgenera, secondly as genera (Newstead 1911). Later, the structure of the male genitalia (França 1919, França \& Parrot 1920, 1921), the alar index and other morphometric indices (França \& Parrot 1921, Larrousse 1921) allowed the erection of subgenera. The importance of female characters such as the cibarial and pharyngeal armatures and spermathecae was introduced by Adler and Theodor (1926), and developed by Sinton (1927a, b, 1928) and Nitzulescu (1931). Classifications at the generic and subgeneric level have subsequently been based on a subjective selection of characters.

\footnotetext{
${ }^{+}$Corresponding author. Fax : +33-4-67-63.0049. E-mail: parasito@sc.univ-montp1.fr

Received 26 March 1998

Accepted 29 July 1998
}

Although the use of these discriminant characters remains the basis of specific identification keys, there are still uncertainties in the systematic position and phylogenetic significance of many supra-specific taxa defined by these characters.

The polythetic concepts contrast with traditional monothetic analysis (Mayr 1969). All phenetic characters are given equal weight (Véron 1969), and are not given a priori discriminant value. Simultaneous consideration of all characters gives each phenon its identity and hierarchical position. Using automatic data processing methods, phenetic analysis shows relationships between groups as graphs of factor analysis, or as dendrograms.

Cladistic analysis indicates apomorphic characters and determines the most parsimonious evolutionary sequence. The final product of the analysis is a cladogram which enables hypotheses of phylogenetic relationships to be made and indicates the direction of evolutionary change in characters.

Numerical taxonomic studies on Arthropoda, whether phenetic or cladistic, have mainly been on Aranea, Coleoptera, Ephemeroptera, Hemiptera, Hymenoptera, Lepidoptera, Mecoptera, Paraneoptera and Plecoptera. Dipterists have been mainly interested in phenetic studies, which have been done on Culicidae (Rohlf 1963, 1977, Hendrickson \& Sokal 1968, Steward 1968, Moss et al. 1979). While various groups, including Psychodidae (Jezek 1983), have been studied by qualitative traditional cladistic analysis, it seems that 
only the genus Toxorhynchites (Simon et al. 1982) and the family Keroplatidae (Matile 1990) have been studied by cladistic methods.

In this study, anatomical characters defining supra-specific groups of phlebotomine sand flies were analysed by phenetical and cladistical methods, as proposed by Lewis et al. (1977).

\section{MATERIALS AND METHODS}

Choice of taxa - For the numerical analysis, supra-specific taxa were chosen as the operational taxonomic units (OTU). Altogether, 21 taxa were considered. In addition to the long-recognised subgenera of Phlebotomus (Lewis 1982), the new taxa Kasaulius Lewis 1982, Transphlebotomus Artemiev \& Neronov 1984 and Chinius Leng 1987 were included. Neophlebotomus França \& Parrot 1920 (synonymous with Rondanomyia, according to Lewis 1978) and Parrotomyia Theodor 1958 were retained in the genus Sergentomyia, sensu França \& Parrot 1920. Of Capensomyia Davidson 1979 and Demeillonius Davidson 1980, only the latter, considered by Artemiev and Neronov (1984) to be a separate genus, was retained.

Selection of characters - A preliminary list was drawn up of morphological characters from males and females classically used by specialists in the identification and classification of sandflies. Many of these were first used by early authors when taxonomic or geographical knowledge of the group was limited. Easily visible structures predominate, notably the male genitalia and the cibarium, pharynx and spermathecae of females. Some characters of the head (mouthparts, palps and antennae), thorax including the wings, and abdomen are also included. Twenty characters were finally retained, relating to the antennae, palps, cibarium, thoracic and abdominal setae and the male and female genital structures.

Definition of character states - Coding requires clearly definable character states. After making a complete list of the possible forms of each structure, grouping was essential to reduce their variety. Wherever possible, grouping took account of known or suspected homologies. Table I shows the 55 states of the 20 characters described in the 21 OTU's, and identifies the state that we believe to be truly plesiomorphic.

Numerical analysis - Following the tabulation of character states for each OTU (Table II), analyses were carried out using an Olivetti M380 XP1 computer. For the phenetic analysis, programmes of the algorithm Analyse de Données of the software Biomeco 2.0 package (Biometrics Group of

TABLE I

Numerical taxonomy of Old World Phlebotominae. Twenty characters and their 55 states

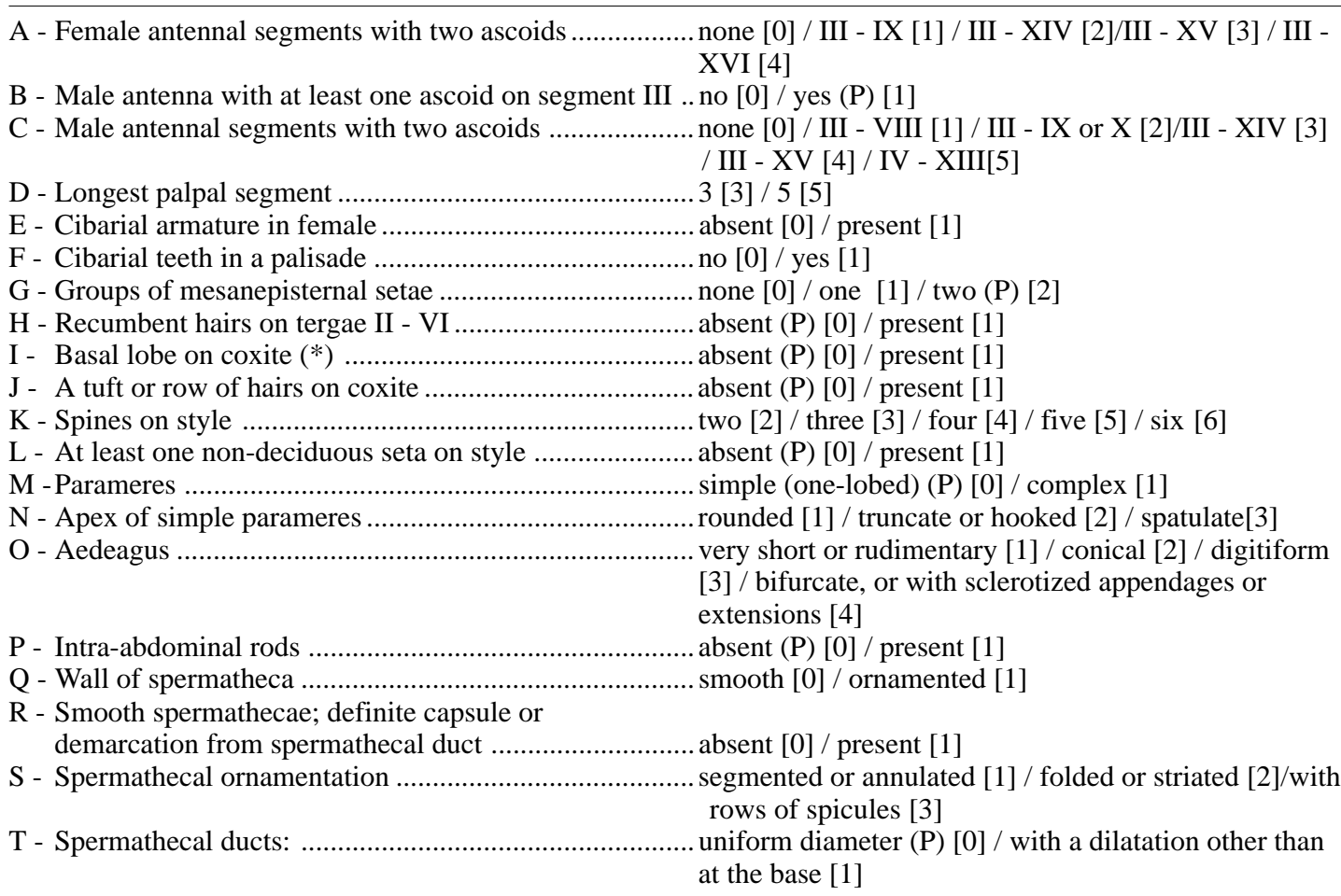

(P): presumed plesiomorphic state; (*): terminology of male genitalia follows Abonnenc (1972). 
TABLE II

Numerical taxonomy of Old World Phlebotominae. Character state matrix. Codes as in Table I

\begin{tabular}{|c|c|c|c|c|c|c|c|c|c|c|c|c|c|c|c|c|c|c|c|c|}
\hline & A & B & $\mathrm{C}$ & $\mathrm{D}$ & $\mathrm{E}$ & $\mathrm{F}$ & G & $\mathrm{H}$ & I & $\mathrm{J}$ & $\mathrm{K}$ & $\mathrm{L}$ & M & $\mathrm{N}$ & $\mathrm{O}$ & $\mathrm{P}$ & Q & $\mathrm{R}$ & $\mathrm{S}$ & $\mathrm{T}$ \\
\hline Phlebotomus & 3 & 1 & 4 & 5 & 0 & - & 1 & 0 & 1 & 1 & 5 & 0 & 1 & - & 2 & 0 & 1 & - & 1 & 0 \\
\hline Paraphlebotomus & 3 & 1 & 4 & 5 & 0 & - & 1 & 0 & 1 & 1 & 4 & 0 & 0 & 3 & 2 & 0 & 1 & - & 1 & 0 \\
\hline Synphlebotomus & 3 & 1 & 2 & 5 & 0 & - & 1 & 0 & 1 & 1 & 5 & 0 & 0 & 3 & 2 & 0 & 1 & - & 1 & 0 \\
\hline Larroussius & 3 & 1 & 1 & 5 & 0 & - & 1 & 0 & 0 & 1 & 5 & 0 & 0 & 1 & 3 & 0 & 1 & - & 1 & 0 \\
\hline Transphlebotomus & 3 & 1 & 4 & 5 & 0 & - & 1 & 0 & 0 & 1 & 5 & 0 & 0 & 1 & 3 & 0 & 1 & - & 2 & 1 \\
\hline Adlerius & 3 & 1 & 4 & 5 & 0 & - & 1 & 0 & 0 & 1 & 5 & 0 & 0 & 1 & 3 & 0 & 1 & - & 2 & 0 \\
\hline Euphlebotomus & 3 & 1 & 2 & 5 & 1 & 0 & 1 & 0 & 0 & 1 & 5 & 0 & 1 & - & 2 & 1 & 1 & - & 1 & 0 \\
\hline Kasaulius & 3 & 1 & 2 & 5 & 1 & 0 & 1 & 0 & 0 & 0 & 5 & 0 & 0 & 2 & 2 & 1 & 1 & - & 1 & 0 \\
\hline Anaphlebotomus & 3 & 1 & 4 & 5 & 1 & 0 & 1 & 0 & 0 & 1 & 4 & 0 & 1 & - & 2 & 0 & 1 & - & 1 & 0 \\
\hline Australophlebotomus & 2 & 1 & 3 & 5 & 1 & 0 & 1 & 0 & 0 & 0 & 3 & 0 & 0 & 2 & 1 & 0 & 1 & - & 2 & 0 \\
\hline Spelaeophlebotomus & 3 & 1 & 2 & 3 & 0 & - & 0 & 0 & 0 & 0 & 4 & 1 & 0 & 1 & 2 & 1 & 0 & 0 & - & 0 \\
\hline Idiophlebotomus & 4 & 0 & 5 & 3 & 1 & 0 & 0 & 0 & 0 & 0 & 3 & 1 & 0 & 1 & 4 & 1 & 0 & 1 & - & 0 \\
\hline Sergentomyia & 3 & 1 & 0 & 5 & 1 & 1 & 0 & 1 & 0 & 0 & 4 & 1 & 0 & 1 & 2 & 0 & 0 & 0 & - & 0 \\
\hline Parrotomyia & 3 & 1 & 0 & 5 & 1 & 1 & 0 & 1 & 0 & 0 & 4 & 1 & 0 & 2 & 2 & 0 & 0 & 1 & - & 0 \\
\hline Neophlebotomus & 3 & 1 & 0 & 5 & 1 & 1 & 0 & 1 & 0 & 0 & 4 & 1 & 0 & 2 & 2 & 0 & 1 & - & 2 & 0 \\
\hline Sintonius & 3 & 1 & 0 & 5 & 1 & 1 & 0 & 1 & 0 & 0 & 4 & 1 & 0 & 2 & 2 & 0 & 1 & - & 1 & 0 \\
\hline Demeillonius & 3 & 0 & 0 & 5 & 1 & 1 & 0 & 1 & 0 & 0 & 6 & 1 & 0 & 1 & 2 & 0 & 1 & - & 1 & 0 \\
\hline Spelaeomyia & 3 & 1 & 4 & 5 & 1 & 1 & 0 & 1 & 1 & 0 & 2 & 1 & 0 & 2 & 1 & 0 & 1 & - & 2 & 1 \\
\hline Grassomyia & 0 & 0 & 0 & 5 & 1 & 1 & 2 & 1 & 0 & 0 & 4 & 1 & 0 & 1 & 2 & 0 & 1 & - & 3 & 0 \\
\hline Parvidens & 3 & 1 & 4 & 5 & 1 & 0 & 2 & 0 & 0 & 1 & 5 & 0 & 1 & - & 2 & 0 & 0 & 1 & - & 0 \\
\hline Chinius & 1 & 1 & 2 & 5 & 1 & 0 & 0 & 0 & 0 & 1 & 4 & 0 & 0 & 1 & 4 & 0 & 1 & - & 1 & 0 \\
\hline
\end{tabular}

[ - ] no state applied to the coded taxon.

CEPE/CNRS, Montpellier) were used. The cladistic analysis used the MIX algorithm (Wagner parsimony), from the PHYLIP programme.

\section{RESULTS}

Phenetic analysis - Correspondence analysis and ascending hierarchical classification yielded similar results. The taxonomic positions of the OTU's are shown in Figs 1 and 2. Separation at the $50 \%$ level, which was taken to correspond to the generic level of classification, indicated at least six taxa at this level: Phlebotomus, Sergentomyia, Australophlebotomus, Spelaeophlebotomus, Idiophlebotomus and Chinius. The genus Phlebotomus appears to contain two clusters. The first contains two groups of closely related subgenera: Phlebotomus, Paraphlebotomus and Synphlebotomus; and Adlerius, Transphlebotomus and Larroussius. The second cluster contains Euphlebotomus, Kasaulius and Anaphlebotomus, with Parvidens loosely attached. Within the genus Sergentomyia, the taxon Spelaeomyia is clearly separate from the others. While conclusions cannot be secure without consideration of outgroups, the phenetic analysis clearly indicates that Parvidens is distinct from Sergentomyia. Abonnenc and Léger (1976) allied
Parvidens with New World sand flies, and the precise position of this group remains to be determined.

Cladistic analysis - Fig. 3 shows the most parsimonious cladogram obtained. This is largely consistent with the phenetic dendrogram (Fig. 2). Taxa conventionally contained in the genera Phlebotomus and Sergentomyia split into two distinct clusters. The left-hand extremity contains Sergentomyia. Spelaeomyia is very distinct. Early off shoots from this branch give rise to Spelaeophlebotomus and Idiophlebotomus. The right-hand branch has an early fork giving Chinius and Australophlebotomus on the one hand, and Parvidens and Anaphlebotomus on the other. This is followed by Euphlebotomus and Kasaulius, then the six apparently most recent taxa: Larroussius, Transphlebotomus, Adlerius, Synphlebotomus, Paraphlebotomus and Phlebotomus. The subgenus Phlebotomus, surprisingly, has a terminal position on this most recent branch of the cladogram, despite the apparently plesiomorphic characters it shares with fossil forms. Indeed, considerations of specific morphological characters in the genus Phlebotomus has confirmed its place among the more primitive subgenera (Rispail \& Léger 1998). 


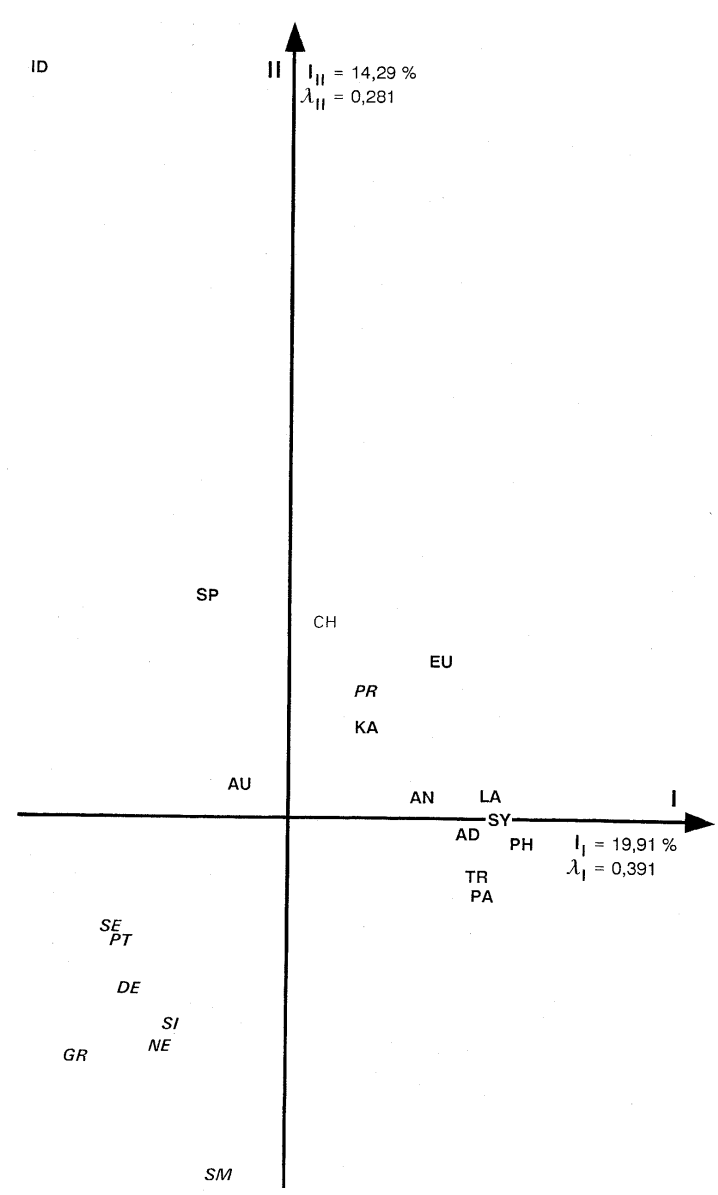

Fig. 1: Old World Phlebotominae. Correspondence analysis of supra-specific taxa. Plane formed by the first two axes. AD: Adlerius Nitzulescu 1931 AN: Anaphlebotomus Theodor 1948 AU: Australophlebotomus Theodor $1948 \mathrm{CH}$ : Chinius Leng 1987 DE: Demeillonius Davidson 1980 EU: Euphlebotomus Theodor 1948 GR: Grassomyia Theodor 1958 ID: Idiophlebotomus Quate \& Fairchild 1961 KA: Kasaulius Lewis 1982 LA: Larroussius Nitzulescu 1931 NE: Neophlebotomus França \& Parrot 1920 PA: Paraphlebotomus Theodor 1948 PT: Parrotomyia Theodor 1958 PR: Parvidens Theodor \& Mesghali 1964 PH: Phlebotomus Rondani \& Berté 1840 SE : Sergentomyia França \& Parrot 1920 SI: Sintonius Nitzulescu 1931 SM: Spelaeomyia Theodor 1948 SP: Spelaeophlebotomus Theodor 1948 SY: Synphlebotomus Theodor 1948 TR: Transphlebotomus Artemiev \& Neronov 1984.

Certain characters, hitherto considered to be of specific interest only may in fact have systematic relevance. For example, the subgenera Grassomyia and Parvidens share with New World groups the presumably plesiomorphic character of "two groups of mesanepisternal setae"; the taxa on the right-hand branch of the cladogram retain only the antero-inferior group of setae, while the groups on the left-hand branch have lost both groups. The proposed phylogeny is consistent, therefore, with the ancestral state of both groups of setae. Furthermore, the cladogram suggests evolutionary sequences for characters for which the direction of evolution was not previously proposed. For example, the presence of a well developed cibarial armature in most of the groups argues in favour of the plesiomorphic nature of this state. With the exception of Spelaeophlebotomus, all the groups lacking, or with a rudimentary armature, lie on the terminal portion of the righ-hand branch, the members of which show various synapomorphies. "Cibarium unarmed" thus appears to be an apomorphic state.

\section{DISCUSSION}

Theodor (1948), in a detailed study of the known forms of phlebotomine sand flies proposed their division into four genera, two of them from Old World. The genus Phlebotomus contained the subgenera Phlebotomus, Paraphlebotomus, Synphlebotomus, Larroussius, Adlerius, Euphlebotomus, Anaphlebotomus, Australophlebotomus and Spelaeophlebotomus. The genus Sergentomyia was divided into the subgenera Sergentomyia, Sintonius and Spelaeomyia.

New discoveries in later years led to the erection of the new subgenera, Idiophlebotomus in Phlebotomus (Quate \& Fairchild 1961), and Parrotomyia, Rondanomyia, Grassomyia (Theodor 1958) and Parvidens (Theodor \& Mesghali 1964) in Sergentomyia. Parvidens contained three species of uncertain position previously included in Euphlebotomus. Abonnenc and Minter (1965) proposed generic status for Spelaeophlebotomus. Hennig (1972), while deploring the inadequacy of many descriptions, considered the Phlebotominae as a monophyletic group composed of three monophyletic sub-groups: the genus Phlebotomus, the genus Sergentomyia (he did not conclusively include Parvidens), and the whole of the two genera Brumptomyia and Lutzomyia. Abonnenc (1972) supported Fairchild's classification (1955), but recognised only the genera Phlebotomus, Warileya and Hertigia and added Spelaeophlebotomus and Idiophlebotomus. Rejecting the excessive division of such a small, homogeneous group of insects, he proposed the division of Phlebotomus into eight subgenera, based largely on chetotaxy. Phlebotomus, Sergentomyia, Parvidens, Spelaeomyia and Grassomyia were the Old World members. Lewis $(1973,1974)$ recognised Phlebotomidae as a family with six genera, two in the Old World and four in the New. The genus Phlebotomus was divided into 11 subgenera, and Sergentomyia into six. Reverting to subfamily status for the entire group, Lewis et al. (1977) attempted to instill a degree of stability, keeping only five genera, each contain- 


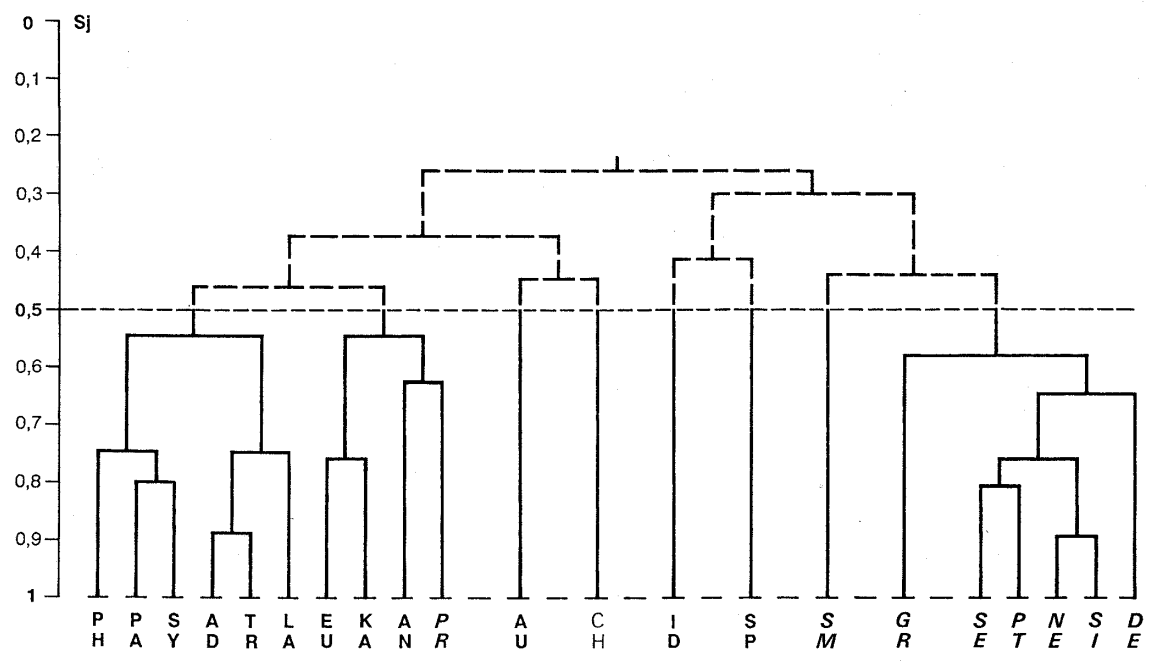

Fig. 2: Old World Phlebotominae. Ascending hierarchical classification. Dendrogram constructed using Jaccard's similarity index and clustering by median linkage. Symbols are the same as in Fig. 1.

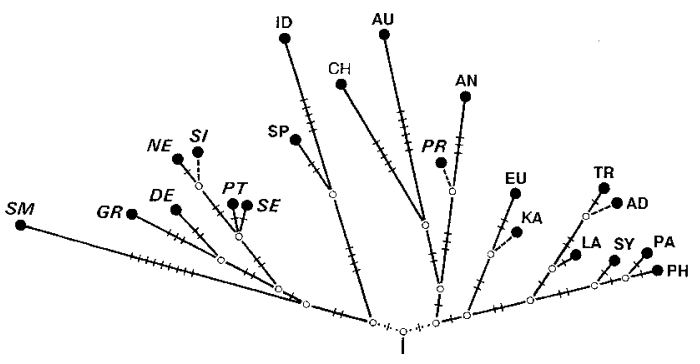

Fig.3: Old World Phlebotominae. Most parsimonious cladogram (78 steps). Symbols are the same as in Fig. 1. Bars indicate the number of steps.

ing many taxa. The Old World genera were Phlebotomus and Sergentomyia, while Lutzomyia, Warileya and Brumptomyia were restricted to the New World. Retaining this 1977 "stable" proposal of five genera, Lewis (1982) declined to recognise generic status for Spelaeophlebotomus and Idiophlebotomus. The genus Phlebotomus thus had 11 subgenera, including Kasaulius which was described at the time. Artemiev and Neronov (1984) included 14 genera in the subfamily Phlebotominae as follows: Australophlebotomus, Brumptomyia, Demeillonius, Grassomyia, Hertigia, Idiophlebotomus, Lutzomyia, Parvidens, Phlebotomus, Psychodopygus, Sergentomyia, Spelaeomyia, Spelaeophlebotomus and Warileya. Including fossil forms, Artemiev (1991) finally divided this subfamily into 24 genera.

Numerical analysis, applied to anatomical char- acters of supra-specific groups of phlebotomine sand flies of the Old World, by and large, coincides with traditional taxonomic opinion, but contributes to the levels of some divisions, and to some specific positions. Thus, this study generally confirms Theodor's classification (1948). It supports the hypothesis of generic rank assigned to the taxa Australophlebotomus, Idiophlebotomus, Spelaeomyia and Spelaeophlebotomus by Abonnenc and Minter (1965), Abonnenc (1972) and Artemiev and Neronov (1984). Also, in another way, it supports Hennig's doubts (1972) about the precise taxonomic position of the taxon Parvidens, particularly as belonging to the genus Sergentomyia. Lastly, it keeps the taxon Demeillonius within the genus Sergentomyia, although this group and Chinius were intuitively placed on the same level.

Quantitative characters, although important for identification, were rarely used in this numerical analysis. On the other hand, characters which have little use in specific identification are sometimes of considerable systematic value. Future studies will benefit from a clearer identification of plesiomorphic characters states; the identification of the sister group would help in this analysis.

A new classification of the Old World phlebotomine sand flies is however proposed (Table III). It is inevitable that this classification will be modified as new information becomes available, especially when larval, pupal and imaginal characters of both Old and New World groups are taken into account, or even extended to encompass all Psychodidae. 
TABLE III

Classification of the Old World Phlebotominae

\begin{tabular}{|c|c|}
\hline Previou & us classification $^{a}$ \\
\hline $\begin{array}{r}\text { Genus I Phleboto } \\
\text {. Subgenus } 1 \\
\text {. Subgenus } 2 \\
\text {. Subgenus } 3 \\
\text {. Subgenus } 4 \\
\text {. Subgenus } 5 \\
\text {. Subgenus } 6 \\
\text {. Subgenus } 7 \\
\text {. Subgenus } 8 \\
\text {. Subgenus } 9 \\
\text {. Subgenus } 10 \\
\text {. Subgenus } 11 \\
\text {. Subgenus } 12\end{array}$ & $\begin{array}{l}\text { tomus } \text { Rondani \& Berté } 1840 \\
1 \text { Adlerius Nitzulescu } 1931 \\
2 \text { Anaphlebotomus Theodor } 1948 \\
3 \text { Australophlebotomus Theodor } 1948 \\
4 \text { Euphlebotomus Theodor } 1948 \\
5 \text { Idiophlebotomus Quate \& Fairchild } 196 \\
6 \text { Kasaulius Lewis } 1982 \\
7 \text { Larroussius Nitzulescu } 1931 \\
8 \text { Paraphlebotomus Theodor } 1948 \\
9 \text { Phlebotomus } \text { Rondani \& Berté } 1840 \\
10 \text { Spelaeophlebotomus Theodor } 1948 \\
11 \text { Synphlebotomus Theodor } 1948 \\
12 \text { Transphlebotomus Artemiev \& } \\
\text { Neronov } 1984\end{array}$ \\
\hline $\begin{array}{r}\text { Genus II Sergentc } \\
\text {. Subgenus } 1 \\
\text {. Subgenus } 2 \\
\text {. Subgenus } 3 \\
\text {. Subgenus } 4 \\
\text {. Subgenus } 5 \\
\text {. Subgenus } 6 \\
\text {. Subgenus } 7 \\
\text {. Subgenus } 8\end{array}$ & $\begin{array}{l}\text { tomyia França \& Parrot } 1920 \\
1 \text { Demeillonius Davidson } 1980 \\
2 \text { Grassomyia Theodor } 1958 \\
3 \text { Neophlebotomus França \& Parrot } 1920 \\
4 \text { Parrotomyia Theodor } 1958 \\
5 \text { Parvidens Theodor \& Mesghali } 1964 \\
6 \text { Sergentomyia França \& Parrot } 1920 \\
7 \text { Sintonius Nitzulescu } 1931 \\
8 \text { Spelaeomyia Theodor } 1948\end{array}$ \\
\hline
\end{tabular}

New proposed classification

Genus I Phlebotomus Rondani \& Berté 1840

. Subgenus 1 Adlerius Nitzulescu 1931

. Subgenus 2 Anaphlebotomus Theodor 1948

. Subgenus 3 Euphlebotomus Theodor 1948

. Subgenus 4 Kasaulius Lewis 1982

. Subgenus 5 Larroussius Nitzulescu 1931

. Subgenus 6 Paraphlebotomus Theodor 1948

. Subgenus 7 Phlebotomus Rondani \& Berté 1840

. Subgenus 8 Synphlebotomus Theodor 1948

. Subgenus 9 Transphlebotomus Artemiev \& Neronov 1984

Genus II Australophlebotomus Theodor 1948

Genus III Idiophlebotomus Quate \& Fairchild 1961

Genus IV Spelaeophlebotomus Theodor 1948

Genus V Sergentomyia França \& Parrot 1920

. Subgenus 1 Demeillonius Davidson 1980

. Subgenus 2 Grassomyia Theodor 1958

. Subgenus 3 Neophlebotomus França \& Parrot 1920

. Subgenus 4 Parrotomyia Theodor 1958

. Subgenus 5 Sergentomyia França \& Parrot 1920

. Subgenus 6 Sintonius Nitzulescu 1931

Genus VI Spelaeomyia Theodor 1948

Genus III Chinius Leng 1987

Genus VII Chinius Leng 1987

Incertae sedis Parvidens Theodor \& Mesghali 1964

$a$ : after Theodor 1948, 1958, Quate \& Fairchild 1961, Theodor \& Mesghali 1964, Davidson 1980, Lewis 1982 and Leng 1987.

\section{ACKNOWLEDGMENTS}

To Prof. F Vaillant (Faculté des Sciences, Grenoble), Prof. DM Jarry, Dr DT Jarry, Dr G Lanotte and Mr E Serres (Faculté de Médecine, Montpellier), Prof. RW Ashford (Liverpool School of Tropical Medicine), Dr L Matile and Dr. J-P Hugot (Muséum National d'Histoire Naturelle, Paris) for their valuable advice.

\section{REFERENCES}

Abonnenc E 1972. Les Phlébotomes de la Région Ethiopienne (Diptera, Psychodidae). Mém ORSTOM, Paris 55: 1-289.

Abonnenc E, Léger N 1976. Sur une classification rationnelle des Diptères Phlebotomidae. Cah ORSTOM, sér Ent Méd Parasitol 14: 69-78.

Abonnenc E, Minter DM 1965. Tables d'identification bilingues des Phlébotomes de la Région Ethiopienne. Cah ORSTOM, sér Ent Méd Parasitol 5: 1-63.

Adler S, Theodor O 1926. On the minutus group of the genus Phlebotomus in Palestine. Bull Ent Res 16: 399-405.

Artemiev MM 1991. A classification of the subfamily Phlebotominae. In Proceedings of the First International Symposium on Phlebotomine Sandflies, Rome. Parassitologia 33 (suppl. 1): 69-77.

Artemiev MM, Neronov VM 1984. Distribution and Ecology of Sandflies of the Old World (genus Phlebotomus), (USRR Com UNESCO Prog Man Biosph), Inst Evol Morphol Anim Ecol, USSR Acad Sci, Moscow: 1-208. [in Russian].

Davidson IH 1980. Sergentomyia transvaalensis, an aberrant phlebotomine from southern Africa (Diptera: Psychodidae). J Ent Soc Sth Afr 43: 65-70.

Fairchild GB 1955. The relationships and classification of the Phlebotominae (Diptera, Psychodidae). Ann Ent Soc Am 48: 182-196.

França C 1919. Notes de zoologie médicale. I. Observations sur le genre Phlebotomus. Broteria 17: 102-160.

França C, Parrot L 1920. Introduction à l'étude sys- 
tématique des Diptères du genre Phlebotomus. Bul Soc Path Exot 12: 695-708.

França C, Parrot L 1921. Essai de classification des Phlébotomes. Archs Insts Pasteur Afr N 1: 279-284.

Hendrickson JA Jr, Sokal RR 1968. A numerical taxonomic study of the genus Psorophora (Diptera: $\mathrm{Cu}-$ licidae). Ann Ent Soc Am 61: 385-392.

Hennig W 1972. Insektenfossilien aus der unteren Kreide. IV. Psychodidae (Phlebotominae), mit einer kritischen Uebersicht über das phylogenetische System der Familie und die bisher beschriebenen Fossilien (Diptera). Stuttg Beitr Naturk 241: 1-69.

Jezek J 1983. Intergeneric relationships of selected tribes of the subfamily Psychodinae (Diptera, Psychodidae). Sb Ent Odd Nar Mus Praze (Acta Ent Mus Nat Pragae) 41: 255-259.

Larrousse F 1921. Etude Systématique et Médicale des Phlébotomes, Vigot, Paris, 103 pp.

Leng YJ 1987. A preliminary survey of phlebotomine sandflies in limestone caves of Sichuan and Guizhou Provinces, South-West China, and description and discussion of a primitive new genus Chinius. Ann Trop Med Parasit 81: 311-317.

Lewis DJ 1973. Phlebotomidae and Psychodidae (Sand-flies and Moth-flies) p. 155-179. In KGV Smith, Insects and other Arthropods of Medical Importance, British Museum (Natural History) (Entomology), London.

Lewis DJ 1974. The biology of Phlebotomidae in relation to leishmaniasis. A Rev Ent 19: 363-384.

Lewis DJ 1978. The phlebotomine sandflies (Diptera: Psychodidae) of the Oriental Region. Bull Br Mus (Nat Hist) (Ent) 37: 217-343.

Lewis DJ 1982. A taxonomic review of the genus Phlebotomus (Diptera: Psychodidae). Bull Br Mus (Nat Hist) (Ent) 45: 121-209.

Lewis DJ, Young DG, Fairchild GB, Minter DM 1977. Proposals for a stable classification of the phlebotomine sandflies (Diptera: Psychodidae). Syst Ent 2: 319-332.

Loew H 1845. Dipterologische Beiträge. 1. Schulprogramm K. Friederich-Wilhems-Gymnasium Posen, Posen, 52 pp.

Matile L 1990. Recherches sur la systématique et l'évolution des Keroplatidae (Diptera, Mycetophiloidea). Mém MNHN, Paris, A (Zool) 148: 682.

Mayr E 1969. Principles of Systematic Zoology, McGraw-Hill, New York, 428 pp.

Moss WW, Steffan WA, Evenhuis NL, Manning DL 1979. The genus Toxorhynchites (Diptera: Culicidae). Analysis of T. splendens and allies using tech- niques of numerical taxonomy. Mosquito Syst 11: 258-274.

Newstead R 1911. The papataci flies (Phlebotomus) of the Maltese islands. Bull Ent Res 2: 47-78.

Nitzulescu V 1931. Essai de classification des Phlébotomes. Annals Parasit Hum Comp 9: 271-275.

Quate LW, Fairchild GB 1961. Phlebotomus sand flies of Malaya and Borneo. Pacif Insects 3: 203-222.

Rispail P, Léger N 1998. Numerical taxonomy of the Old World Phlebotominae (Diptera: Psychodidae). 1. Considerations of morphological characters in the genus Phlebotomus Rondani \& Berté 1840. Mem Inst Oswaldo Cruz 93: 773-785.

Rohlf FJ 1963. Classification of Aedes by numerical taxonomic methods (Diptera: Culicidae). Ann Ent Soc Am 56: 798-804.

Rohlf FJ 1977. Classification of Aedes mosquitos using statistical methods. Mosquito Syst 9: 372-388.

Rondani C 1840. Sopra una Specie di Insetto Dittero, Memoria prima per servire alla ditterologia italiana $\mathrm{n}^{\circ} 1$, Donati, Parma, $16 \mathrm{pp}$.

Scopoli JA 1786. Deliciae Florae et Faunae Insubricae, Pavia, 1, 85 pp.

Simon CM, Steffan WA, Moss WW, Evenhuis NL 1982. The genus Toxorhynchites (Diptera: Culicidae). Numerical phylogenetic analysis of $T$. splendens and allies with phenetic comparisons. Mosquito Syst 14: 221-260.

Sinton JA 1927a. Notes on some indian species of the genus Phlebotomus. XIX. The value of the female genitalia in the identification of species. Indian $J$ Med Res 15: 21-27.

Sinton JA 1927b. Notes on some indian species of the genus Phlebotomus. XX. The morphology of the buccal cavity in some species. Indian JMed Res 15:29-32.

Sinton JA 1928. The synonymy of the asiatic species of Phlebotomus. Indian J Med Res 16: 297-324.

Steward CC 1968. Numerical classification of the Canadian species of the genus Aedes (Diptera: Culicidae). Systc Zool 17: 426-437.

Theodor O 1948. Classification of the Old World species of the subfamily Phlebotominae (Diptera, Psychodidae). Bull Ent Res 39: 85-115.

Theodor O 1958. Psychodidae, Phlebotominae, p. 1-55. In E Lindner, Die Fliegen der Palaearktischen Region, Vol. 9, Psychodidae, E. Schweizerbart'sche Verlag, Stuttgart.

Theodor O, Mesghali A. 1964. On the Phlebotominae of Iran. J Med Ent 1: 285-300.

Véron M 1969. Taxonomie numérique et classification des Bactéries. Bull Inst Pasteur 67: 2739-2766. 
794 Numerical Taxonomy of Old World Phebotominae • P Rispail, N Léger 